\title{
Induction of implantation by androgens in mice with delayed implantation
}

\author{
S. K. Roy, Jayasree SenGupta and S. K. Manchanda \\ Department of Physiology, All India Institute of Medical Sciences, Ansari Nagar, \\ New Delhi-110016, India
}

\begin{abstract}
Summary. Testosterone and $5 \alpha$-dihydrotestosterone ( $5 \alpha-\mathrm{DHT})$ were able to mimic the action of oestradiol-17 $\beta$ in initiating implantation in ovariectomized, progesterone-treated mice. Cyproterone acetate and CI-628 were capable of inhibiting the testosterone-induced response, but CI-628 citrate prevented only the $5 \alpha$-DHT-mediated implantation reaction. It is suggested that testosterone acts through testosterone and oestrogen receptors while 5a-DHT acts only through oestrogen receptors.
\end{abstract}

\section{Introduction}

The hormonal control of implantation can be studied in the mouse and the rat by experimentally delaying nidation. Ovariectomy performed soon after ovulation and mating prevents implantation and the embryo can be retained in a metabolically depressed state of dormancy if progesterone is given daily (Yoshinaga \& Adams, 1966). Oestrogen sensitization of these animals results in increased rates of DNA, RNA and protein synthesis by the embryos which will then implant (McLaren, 1973). The site and mode of action of oestrogen in the induction of nidation is not yet known; it may act directly on the embryo or cause the removal of some inhibitors thought to be present in the uterine environment (Psychoyos, 1969; Weitlauf, 1978). Humphrey (1967) has shown that in the ovariectomized, progesterone-treated mouse, oestrogen action can be mimicked by testosterone propionate. He suggested that this effect of testosterone or its derivatives on implantation could be a direct effect of the steroids or due to oestrogenic metabolites following conversion of testosterone to oestradiol in non-ovarian tissues.

Androgens such as testosterone and $5 \alpha$-dihydrotestosterone ( $5 \alpha$-DHT) have both uterotrophic and anti-uterotrophic effects in rats and mice (Dorfman, Kincl \& Ringgold, 1961; Armstrong, Moon \& Leung, 1976). Testosterone binds with cellular receptors present in the uterine tissue which are specific for testosterone and have low affinity for $5 \alpha$-DHT (Giannopolous, 1973), although in prostatic tissue the receptors have a high affinity for $5 \alpha$-DHT (Giannopolous, 1973). The testosterone-induced increase in uterine weight can be effectively inhibited by specific testosterone receptor inhibitors (Lerner, Hilf, Turkheimer, Michel \& Engel, 1966; Boris, DeMartino \& Trmal, 1971). In the present study, the cellular mechanism of action of testosterone and $5 \alpha$-DHT on the initiation of implantation was studied by using two steroid receptor inhibitors.

\section{Materials and Methods}

Adult, virgin Swiss mice weighing 20-25 g were kept under natural lighting conditions and fed ad libitum on standard pellet diet and water. The females were caged overnight with males and the day of finding of a copulatory plug was designated Day 1 of pregnancy. All mice were 
bilaterally ovariectomized on Day 3, care being taken to avoid any excessive bleeding or damage to the oviducts. The ovaries were inspected for the presence of corpora lutea as a positive sign of ovulation. The mice were given daily i.p. injections of $1 \mathrm{mg}$ progesterone until the end of the experiment.

Progesterone and oestradiol-17 $\beta$ were obtained from Sigma Chemical Co. (U.S.A.), testosterone and $5 \alpha$-dihydrotestosterone were obtained from Steraloids Inc. (U.S.A.), CI-628 citrate was from Parke-Davis Co. (U.S.A.) and cyproterone acetate was from Schering AG (Berlin, Germany).

The mice were allocated to 3 groups. Those in Group I were given a single i.p. injection of oestradiol-17 $\beta$, testosterone or $5 \alpha$-DHT at different dosages at 10:00 h on Day 8. Group II mice were first injected i.p. with $5000 \mu \mathrm{g}$ cyproterone acetate on Day 8 followed $3 \mathrm{~h}$ later with $500 \mu \mathrm{g}$ testosterone, $1500 \mu \mathrm{g} 5 \alpha$-DHT, or $0.25 \mu \mathrm{g}$ oestradiol-17 $\beta$. Mice in Group III received, i.p. on Day 8, $2500 \mu \mathrm{g}$ CI-628 citrate alone or followed 3 h later with $1500 \mu \mathrm{g} 5 \alpha$-DHT or 500 $\mu \mathrm{g}$ testosterone. All animals were killed on Day 11, and the uteri were removed and checked for implantation sites which were processed for histological studies. Uteri bearing no implantations were flushed with saline $(9 \mathrm{~g} \mathrm{NaCl} / \mathrm{l})$ to recover blastocysts in delay.

\section{Results}

All three steroids given independently (Group I) were able to induce implantation (Table 1). The implantations obtained on Day 11 from the testosterone- and 5 $\alpha$-DHT-treated animals were morphologically normal and comparable in developmental stage to those obtained after oestradiol injection. Treatment of mice with different doses of $5 \alpha$-DHT showed that there was a dose response (Table 2). All the implantations examined histologically on Day 11 appeared normal.

Table 1. Effects of steroids on implantation in mice with experimentally delayed blastocysts

\begin{tabular}{lcccc}
\hline $\begin{array}{c}\text { Treatment } \\
\text { on Day 8 }\end{array}$ & Dose & $\begin{array}{c}\text { No. of mice } \\
\text { treated }\end{array}$ & $\begin{array}{c}\text { No. with } \\
\text { implantation } \\
\text { sites on } \\
\text { Day 11 (\%) }\end{array}$ & $\begin{array}{c}\text { Total no. of } \\
\text { implantations }\end{array}$ \\
\hline Vehicle* & $0.1 \mathrm{ml}$ & 4 & $0(0)$ & 0 \\
Oestradiol-17ß & $0.25 \mu \mathrm{g}$ & 4 & $3(75)$ & 30 \\
Testosterone & $500 \mu \mathrm{g}$ & 10 & $5(50)$ & 19 \\
5a-DHT & $1500 \mu \mathrm{g}$ & 15 & $11(73)$ & 20 \\
\hline
\end{tabular}

* Peanut oil.

Table 2. Effects of different doses of $5 a$-DHT on implantation in mice with experimentally delayed blastocysts

\begin{tabular}{lcccc}
\hline $\begin{array}{c}\text { Treatment } \\
\text { on Day 8 }\end{array}$ & Dose $(\mu \mathrm{g})$ & $\begin{array}{c}\text { No. of } \\
\text { mice treated }\end{array}$ & $\begin{array}{c}\text { No. with } \\
\text { implantations } \\
\text { on Day 11 (\%) }\end{array}$ & $\begin{array}{c}\text { No. of } \\
\text { implantations }\end{array}$ \\
\hline None (control)* & Nil & 4 & $0(0)$ & 0 \\
5a-DHT & 500 & 20 & $1(5)$ & 10 \\
& 1000 & 16 & $6(37.5)$ & 20 \\
& 1500 & 15 & $11(73)$ & 62 \\
\hline
\end{tabular}

* $0.1 \mathrm{ml}$ peanut oil. 
The results with Group II animals are shown in Table 3. When testosterone was given after cyproterone acetate there were significantly fewer $(P=0.05)$ implantations than when testosterone was given alone (Table 1). The implantation numbers after treatment with $5 \alpha$-DHT and oestradiol were similar to those given in Table 1.

Table 3. Effect of cyproterone acetate on implantation induced in mice with experimentally delayed blastocysts

\begin{tabular}{|c|c|c|c|c|c|}
\hline $\begin{array}{l}\text { Treatment } \\
\text { on Day } 8\end{array}$ & $\begin{array}{c}\text { Dose } \\
(\mu \mathrm{g})\end{array}$ & $\begin{array}{l}\text { No. of mice } \\
\text { treated }\end{array}$ & $\begin{array}{c}\text { No. with } \\
\text { implantations } \\
\text { on Day } 11(\%)\end{array}$ & $\begin{array}{c}\text { No. of } \\
\text { implantations }\end{array}$ & $\begin{array}{l}\text { No. of } \\
\text { blastocysts } \\
\text { flushed }\end{array}$ \\
\hline $\begin{array}{c}\text { Cyproterone } \\
\text { acetate }+ \\
\text { testosterone }\end{array}$ & $\begin{array}{c}5000 \\
+ \\
500\end{array}$ & 10 & $2(20)^{\mathrm{a}, \mathrm{b}}$ & 9 & 25 \\
\hline $\begin{array}{c}\text { Cyproterone } \\
\text { acetate }+ \\
5 \alpha \text {-DHT }\end{array}$ & $\begin{array}{c}5000 \\
+ \\
1500\end{array}$ & 15 & $14(93 \cdot 3)^{b}$ & 59 & 4 \\
\hline $\begin{array}{l}\text { Cyproterone } \\
\text { acetate }+ \\
\text { oestradiol-17 } \beta\end{array}$ & $\begin{array}{l}5000 \\
+ \\
0.25\end{array}$ & 9 & $6(66.6)^{a}$ & 32 & 0 \\
\hline
\end{tabular}

$a: \chi^{2}=6 \cdot 36$, d.f. $=1, P<0.02 ; b: \chi^{2}=10.42$, d.f. $=1, P<0.01$ (using Yates correction factor).

Table 4. Effect of CI-628 citrate on androgen-induced implantation in mice with experimentally delayed blastocysts

\begin{tabular}{lcccc}
\hline $\begin{array}{c}\text { Treatment } \\
\text { on Day } 8\end{array}$ & $\begin{array}{c}\text { Dose } \\
(\mu \mathrm{g})\end{array}$ & $\begin{array}{c}\text { No. of } \\
\text { mice } \\
\text { treated }\end{array}$ & $\begin{array}{c}\text { No. with } \\
\text { implantations } \\
\text { on Day 11 }\end{array}$ & $\begin{array}{c}\text { No. of } \\
\text { blastocysts } \\
\text { flushed }\end{array}$ \\
\hline $\begin{array}{l}\text { CI-628 citrate } \\
\text { CI-628 citrate } \\
+5 \alpha \text {-DHT }\end{array}$ & $\begin{array}{c}2500 \\
2500\end{array}$ & 6 & 0 & 26 \\
$\begin{array}{c}\text { CI-628 citrate } \\
+ \text { testosterone }\end{array}$ & $\begin{array}{c}2500 \\
+500\end{array}$ & 8 & 0 & 26 \\
\hline
\end{tabular}

Treatment of Group III mice with CI-628 citrate did not initiate implantation and this effect was not overcome by $5 \alpha$-DHT or testosterone (Table 4). All the blastocysts recovered by flushing from the uterus were of normal appearance.

\section{Discussion}

In this report we have shown that testosterone and $5 \alpha$-dihydrotestosterone given to mice experiencing an experimental delay of implantation will induce implantation which appears on Day 11 to be morphologically normal and similar to that induced by oestrogen. However, the doses of androgen required for this effect were 2000 times higher than that for oestradiol-17 $\beta$, as found by Giannopolous (1973) for the induction of uterine growth in immature rats.

Giannopolous (1973) proposed that androgen-induced uterotrophic responses were mediated by direct interaction with specific cellular binding components. In the present study we used two steroid antagonists, CI-628, a non-steroidal antioestrogen (Capony \& Rochefort, 1975) with pro-oestrogenic activity (Callantine et al., 1966), and cyproterone acetate which is an antiandrogen (Whalen \& Luttge, 1969), to investigate the mode of action of testosterone and $5 \alpha-$ DHT in the induction of implantation. Both the antagonists acted as competitive inhibitors of steroid receptors. The inhibition of the testosterone action in cyproterone acetate-treated mice (Table 3 ) suggested that the testosterone action might be through specific uterine androgen 
receptors which were being blocked by cyproterone acetate. However, even after blockade of the oestrogen receptors by treatment with CI-628, testosterone failed to initiate implantation (Table 4 ), indicating that androgen and oestrogen receptor systems were involved. The precise mechanism of action of testosterone in the uterus and in oestrogen-dependent tissues such as mammary tumours is as yet incompletely known. Various investigators have shown that androgen-induced uterotrophic responses are antagonized by the antiandrogens BOMT and Anorprogesterone (Lerner et al., 1966; Boris et al., 1971) but can not be counteracted by antioestrogens such as MER 25 or clomiphene (Gonzales-Diddi, Komisaruk \& Beyer, 1972; Datta, Roy \& Das, 1975). On the other hand, Zava \& McGuire (1978) have presented evidence that in the oestrogen-responsive human breast cancer cell line MCF-7, which has receptors for androgen and oestrogen, androgenic stimulation of tissue growth occurred by the activation and translocation of oestrogen receptors following specific binding with the androgens. In the present study we have shown, using a uterine model, that testosterone at one dose level $(500 \mu \mathrm{g})$ induced implantation in mice through testosterone or oestrogen receptor binding.

The non-aromatizable androgen $5 \alpha$-DHT is also capable of inducing implantation, and our results with the antioestrogen CI-628 (Tables 3 and 4) support the contention that $5 \alpha$-DHT mediates its effect through the oestrogen and not the androgen receptor system. Similar studies on the rat uterus and MCF-7 cell line have shown that 5 $\alpha$-DHT-induced uterotrophic and growth-promoting responses resulted from the binding and translocation of oestrogen receptors and the effects were blocked by the antioestrogens CI-628 and Nafoxidine (Ruh \& Ruh, 1975; Katzenellenbogen \& Ferguson, 1975; Gracia \& Rochefort, 1977; Zava \& McGuire, 1978).

Callantine et al. (1966) have shown that oestrone can provoke implantation of blastocysts delayed by progesterone in rats treated with CI-628, indicating that the embryos were not damaged. We have confirmed these findings for mice treated with CI-628 and oestradiol-17 $\beta$. Oestradiol-17 $(0.25 \mu \mathrm{g})$ given $3 \mathrm{~h}$ after CI-628 $(250 \mu \mathrm{g})$ to mice with delay of implantation induced 25 implantations in 4 out of 7 animals. The same dose of the steroid when given alone yielded 21 implantations in 4 out of 5 mice. All the implantations examined histologically on Day 11 appeared normal. That the effect of androgen antagonists on the blastocysts was not one of general toxicity has been shown by the restoration of implantation when oestradiol-17 $\beta$ was given to mice treated with cyproterone acetate (Table 3).

The physiological significance of testosterone action in the female reproductive cycle remains to be elucidated. Treatment of rats with an antiserum to testosterone to inhibit the preovulatory rise of testosterone resulted in blockade of the secondary FSH peak observed during oestrus (Gay \& Tomacari, 1974). Mice exhibited an increase in serum testosterone concentrations before the oestrogen and LH peaks which occur $24 \mathrm{~h}$ before implantation (Barkley, Michael, Geshwind \& Bradford, 1977). However, the biological significance of an androgen-induced implantation reaction is not yet known.

This work was supported by funds from the Indian Council of Medical Research and the Family Planning Foundation of India. We thank Parke-Davis Co., U.S.A., and Schering AG, Berlin, for their generous gifts of CI-628 citrate and cyproterone acetate, respectively.

\section{References}

Armstrong, D.T., Moon, Y.S. \& Leung, P.C.K. (1976) Uterotropic effects of testosterone and $5 \alpha$-dihydrotestosterone in intact and ovariectomized immature female rats. Biol. Reprod. 15, 107-114.

Barkley, M.S., Michael, S.D., Geshwind, I.I. \& Bradford, G.E. (1977) Plasma testosterone during pregnancy in the mouse. Endocrinology 100, 1472-1475.

Boris, A.L., DeMartino, L. \& Trmal, T. (1971) Some endocrine studies of a new antiandrogen, $6 \alpha$-bromo-
17 $\beta$-hydroxy-17 $\alpha$-methyl-4-oxa- $5 \alpha$-androstan-3-one (BOMT). Endocrinology 88, 1086-1091.

Callantine, M.R., Humphrey, R.R., Lee, S.L., Windsor, B.L., Schottin, N.R. \& O'Brien, O.P. (1966) Action of estrogen antagonist on reproductive mechanism in the rat. Endocrinology 79, 153-167.

Capony, F. \& Rochefort, H. (1975) In vivo effect of antiestrogens on the localisation and replenishment of estrogen receptor. Mol. cell. Endocr. 3, 233-251. 
Datta, J.K., Roy, S. \& Das, R.P. (1975) Effect of clomiphene on the ponderal, histological and biochemical changes induced by stilbestrol and testosterone in the uterus of rats. Steroids 25, 163-168.

Dorfman, R.I., Kincl, F.A. \& Ringgold, H.J. (1961) Antiestrogen assay of neutral steroids administered by subcutaneous route injections. Endocrinology 68, 17-24.

Gay, V.L. \& Tomacari, R.L. (1974) Follicle-stimulating hormone secretion in the female rat: cyclic release is dependent on circulating androgen. Science, N.Y. 184, 75-76.

Giannopolous, G. (1973) Binding of testosterone to uterine components of the immature rat. J. biol. Chem. 248, 1004-1010.

Gonzales-Diddi, M., Komisaruk, B. \& Beyer, C. (1972) Differential effect of testosterone and dihydrotestosterone on the diverse uterine tissues of the ovariectomized rats. Endocrinology 91, 1129-1132.

Gracia, M. \& Rochefort, H. (1977) Androgens on the estrogen receptor. II Correlation between nuclear translocation and uterine protein synthesis. Steroids 29, 111-126.

Humphrey, K.W. (1967) The induction of implantation in the mouse after ovariectomy. Steroids 10, 591600 .

Katzenellenbogen, B.S. \& Ferguson, E.R. (1975) Antiestrogen action in the uterus: biological ineffective- ness of nuclear bound estradiol after antiestrogen. Endocrinology 97, 1-12.

Lerner, L.J., Hilf, R., Turkheimer, A.R., Michel, L. \& Engel, S.L. (1966) Effect of hormone antagonists on morphological and biochemical changes induced by hormonal steroids in the immature rat uterus. Endocrinology 78, 111-124.

McLaren, A. (1973) Blastocyst activation. In The Regulation of Mammalian Reproduction, pp. 321328. Eds S. J. Segal, R. Crozier, P. A. Corfman \& P. G. Condiliffe. C. C. Thomas, Springfield, Illinois.

Psychoyos, A. (1969) Hormonal requirements for egg implantation. Adv. Biol. Sci. 4, 275-290.

Ruh, T. \& Ruh, M.F. (1975) Androgen induction of a specific uterine protein. Endocrinology 97, 11441150.

Whalen, R.E. \& Luttge, W.G. (1969) Contraceptive properties of the antiandrogen cyproterone acetate. Nature, Lond. 223, 633-634.

Weitlauf, H.M. (1978) Factors in mouse uterine fluid that inhibit the incorporation of $\left[{ }^{3} \mathrm{H}\right]$ uridine by blastocyst in vitro. J. Reprod. Fert. 52, 321-325.

Yoshinaga, K. \& Adams, C.E. (1966) Delayed implantation in the spayed, progesterone treated adult mouse. J. Reprod. Fert. 12, 593-595.

Zava, D.T. \& McGuire, W.L. (1978) Androgen action through estrogen receptor in a human breast cancer cell line. Endocrinology 103, 624-631.

Received 30 April 1979 